\title{
Impact of Customer-Supplier Relationships and Facilitation of Credit on Development of Micro Enterprises in KZN Rural Areas
}

\author{
Itumeleng Judith Sepeame
}

Department of Entrepreneurial Studies and Management, Faculty of Management Sciences Durban University of Technology, KwaZulu Natal, Durban, South Africa

Dr Marie de Beer

Department of Entrepreneurial Studies and Management, Faculty of Management Sciences Durban University of Technology, KwaZulu Natal, Durban, South Africa

Email: marieb@dut.ac.za

\section{Doi:10.5901/mjss.2014.v5n20p819}

Abstract

The aim of the research is to identify the impact of customer-supplier relationships in terms of facilitation of credit, on the development of Micro Enterprises in the Sobonakhona Makhanya Tribal Area. Micro enterprises in three rural villages - Adams Mission, Madundube, and Umbumbulu were identified as the target population. Three research assistants using a convenient sampling method selected the research respondents. This is a qualitative study, which entailed an empirical research by means of a questionnaire as a measuring instrument. It was found that the nature of the relationship between the suppliers and institutions and Micro Enterprises influenced their accessibility to credit facilities. Most were rejected credit while some did not apply because they assumed that their application would be rejected. It was found, however, that those that applied to wholesalers for credit were successful. The rejections of the respondents' applications were mostly based on their inability to provide sufficient collateral and business plans. Most importantly, those respondents that did obtain credit, experienced positive changes as a result of their increased facilities.

Keywords: Micro Enterprises, customer-supplier, relationships, credit facilities, development

\section{Introduction}

Small business owners normally live from hand to mouth and very seldom make elaborate arrangements for financing. Their relationship with suppliers is mainly on a cash basis and whenever they require finance over a set period, they find it difficult to arrange, mainly because of the poor customer supplier relationships.

Some of the challenges facing Micro Enterprises in KZN in South Africa (SA) in this respect, have an impact on their growth and development, and need to be overcome. Examples of the challenges are, access to start up and expansion finance, identifying markets, availability of appropriate technology and human resources (Nieman, Hough, Nieuwenhuizen, 2003). It is known that financial institutions are cautious when it comes to lending money to Micro Enterprises and this is seen to be based on the limited size of Micro Enterprises (Kroon 1997). Micro Enterprises are also often discriminated against on the basis of purchase, rent and interest rate, and the significance of this constraint is recognized all over the world. This could be because of the high rate of failure among Micro Enterprises, which may result in non-payment of credit received (Nieman et al 2003).

Regardless of the problems experienced by Micro Enterprises, it is essential to stimulate their development, as they are likely to be the job creators of the future, as well as the providers of subsistence level employment opportunities. Micro Enterprises have a major role to play in the South African economy, in terms of employment creation, income generation and output growth. They are considered a vehicle through which the lowest income earners in SA are able to gain access to economic opportunities, yet they are mostly discriminated against when it comes to making funds available to them.

In order to achieve the overall purpose of the study, it is essential to identify the nature of customer-supplier relationships between financial institutions and Micro Enterprises, the types of credit facilities available to Micro Enterprises, and the minimum amount of credit available to them. It is also important to understand the reasons for the lack of access to credit facilities by the Micro Enterprises and to identify financial institutions' restrictions of access to 
credit facilities. For those Micro Enterprises that have access to credit facilities, it is important to identify the nature and extent of business development after obtaining credit, the payment terms with suppliers, as well as procedural requirements.

The following hypotheses were developed:

H1: There is a significant correlation between customer-supplier relationship and credit facilities accessible to Micro Enterprises.

$\mathrm{H} 2$ : There is a significant correlation between credit facilities and the nature of Micro Enterprise development.

H3: There is a significant correlation between the nature of payment terms with suppliers and credit institutions' restrictions of access to credit facilities for Micro Enterprises.

\section{Literature Review: Customer-Supplier Relationships}

Rural Micro Enterprises contain a diverse mix of enterprises, with the most common forms in retail and service-related activities other than manufacturing enterprise, which are mostly found elsewhere (Rogerson 2006). More specifically, the range of rural Micro Enterprises encompasses different activities. In retail the most common are tuck shops, whereas in services the most common are hair salons. For the few manufacturing or construction enterprises, the activities range from beer brewing to baking (Rogerson 2006) (Table 1)

Table 1: Classification of Micro Enterprises activities

\begin{tabular}{|l|l|l|}
\hline Retail & Services & Manufacturing \\
\hline Bottle stores & Electrical repairs & Baking \\
Cafes & Hair salons & Beer brewing \\
General dealers & Motor repairs & Brick making \\
Hardware stores & Panel beating & Clothing \\
Shebeens & Shoe repairs & Craft production \\
Spazas & Transport & Dress making \\
Tuck shops & & Knitting \\
& & Metal work \\
& & Small-scale maize milling \\
\hline
\end{tabular}

Source: Rogerson 2006

\subsection{Funding used by Micro Enterprises}

Finding finance or gaining financial support for any new venture is one of the main difficulties experienced by entrepreneurs (Smorfitt 2009).The greatest need, faced by enterprises operating in the Micro Enterprise category, is working capital to purchase supplies and inputs. In general this has been satisfied by family and friends, informal moneylenders, NGO's and credit obtained from suppliers.

The financial institutions available in South Africa mainly serve individuals and business that have financial needs for personal or business use. Commercial banks are the main source of finance to commerce and industry. However, as they tend to raise only short-term loans, i.e. money that can be repaid within a period of less than a year (one to 12 months), they only lend in the short term. The commercial banks offer loans and overdrafts, discounting of bills, and discounted credit facilities.

Alternatively, there are also merchant banks that specifically provide a wide variety of associated financial services, such as leasing, insurance, pension and share transfer. Funding can, in addition, also be obtained from insurance companies. Under certain conditions, policyholders can borrow money against the surrender value of their policies (Huyghebaert, Van de Gucht, and Van de Hulle 2007).

Government sponsored institutions are also classified as financial institutions, which assist people to gain access to funds for personal as well as business use. These include, the Industrial Development Corporation (IDC), which grants long-, medium-, and short-term credit to large businesses, takes up shares, and does underwriting; The Small Business Development Corporation (SBDC), established with the specific objective of encouraging the development of small business in South Africa. The SBDC does this by offering loan capital for a period ranging from three to 10 years, at competitive interest rates. Another institution that assists with funding, is that of The Development Bank, which provides 
financial assistance for the promotion of industrial undertakings in less developed areas. Assistance is provided mainly in the form of medium- and long-term loans. In addition, there is also the Land and Agricultural Bank of South Africa that advances money to farmers, co-operatives, agricultural societies and companies, as well as regulatory boards. Intermediate and short-term loans are granted to farmers in the form of cash credit accounts, while loans to agricultural co-operatives may be long or short-term.

\subsection{Types of loans}

It is maintained that, to start a business, a person may apply for a loan from a bank or any financial lending institution. Instead of borrowing large amounts of money to buy fixed assets, a business can arrange for the use, but not ownership, of the required assets. This could be either on a lease or by means of a hire purchase transaction. Obtaining an asset on hire purchase is also useful when buying expensive equipment for the business. There are however, strict requirements for hire purchase transactions.

Huyghebaert et al (2007) states that trade credit is the cheapest and mostly freely available source of short-term finance, and explains that acceptance credit is a facility offered by merchant banks, which is, however, not available to small businesses.

\subsection{Summary of theoretical framework}

Micro Enterprises are broadly categorised and are commonly known as a category under Small Medium and Micro Enterprises (SMMEs). The most common trading of the respondents is found to be in retail and service related activities. In retail, the most common is tuck shops, whereas in services, it is hair salons. For the few manufacturing or construction enterprises, the activities range from beer brewing to baking (Rogerson 2006). The greatest need faced by Micro Enterprises with regards to funding, is working capital, which is commonly provided by family and friends, informal moneylenders, NGO's and through credit obtained from suppliers. The financial institutions available in South Africa mainly serve individuals and businesses that have financial needs for personal or business use. There are various sources of finance; Commercial and Merchant banks, Insurance companies, and Government sponsored institutions, such as the IDC and SBDC. Although these institutions offer loans (mainly long term), overdraft and discounting of bills, as well as discount credit facilities, they tend to raise only short term money. To acquire the assets required to start a business, the Micro Enterprise could also lease the assets or purchase them on a hire purchase agreement. It is, however, maintained by Huyghebaert et al (2007) that trade credit is the cheapest and most freely available source of short-term finance.

\section{Research Methodology}

The nature of the research was qualitative, aimed at determining the attitudes and behaviour of respondents towards accessible credit facilities, thereby determining customer-supplier relationships. Three research assistants, who were literate in both English and isizulu, were recruited to assist with the research project, mainly because they could read and write IsiZulu and English very well. The assistants had to distribute the questionnaires to small businesses in the selected area and aid respondents in completing the questionnaires, as findings show low literacy levels.

\subsection{Population}

The target area, the Sobonakhona Makhanya (SM) area, is situated on the South Coast of Kwa-Zulu Natal. It is a traditional area governed by an Inkosi. The area is divided into eight villages: Adams Mission, Entinyane, Entsimbini, Ezimbokodweni, Folweni, Madundube, Mvuzane and Umbumbulu. Each area has an Induna overseeing it. Micro Enterprises in three of the villages were identified as the target population. The other villages were in more built up areas and could be considered to be peri-urban; therefore the Micro Enterprises in these areas were not included in this study.

\subsection{Participants}

The research assistants, using a convenience sampling method, selected the research participants. They had to identify a business that could be easily accessed and was already established. Because of the tribal nature and the lie of the land, it was impossible to define a sampling frame. The target area was well defined but not all Micro Enterprises were 
accessible, which resulted ina decision to use a convenience sampling approach, where the research assistants had to go around the area and distribute the questionnaires to Micro Enterprises that were convenient to access. A total of 60 Micro Enterprises from three different villages in the SM area, Adams Mission, Umbumbulu and Madundube, formed the sample.

Three research assistants were used to not only administer the questionnaires but to also conduct semi-structured interviews with the selected respondents in the village in which they lived or that is located close to their own village. The businesses identified were within the category of SMMEs (Micro Enterprises), as defined by the Department of Trade and Industry (1998).

\section{Summary of Research Findings}

The research findings will cover the profiles of the respondents, the nature of customer-supplier relationships, the nature and accessibility of credit facilities for Micro Enterprises, reasons for lack of access to credit facilities, nature of payment terms, and the nature and extent of Micro Enterprise development.

\subsection{Profiles of respondents}

The profile of the respondents, such as gender, age, literacy level, education and training could have an impact on their accessibility to credit facilities (See Table 4.2). For this reason, it was important to identify the impact of the respondents' profiles on the accessibility of credit.

Table 2: Findings on the profile of research participants

\begin{tabular}{|c|c|}
\hline Gender & The study indicated that there are more (60\%) male owners in the study area. \\
\hline Age & $\begin{array}{l}\text { A large number (38\%) of business owners are in the age category of } 20 \text { to } 29 \text { years, as well as in the over } \\
40 \text {-year age group }\end{array}$ \\
\hline Literacy & $\begin{array}{l}\text { A large number of respondents were found to be literate, with the overall literacy of females (86\%) } \\
\text { respondents which was higher than that of males }(75 \%) \text {. }\end{array}$ \\
\hline Education & $\begin{array}{l}\text { The majority ( } 66 \%) \text { of the respondents have secondary education } \\
\text { The majority of those that had tertiary education are female } \\
\text { In general males are better educated than females (Table 3) }\end{array}$ \\
\hline Training & $\begin{array}{l}\text { This study showed that the majority (78\%) of respondents did not have any training on how to start or run } \\
\text { a business }\end{array}$ \\
\hline Number of employees & $\begin{array}{l}\text { Many (84\%) respondents who are business owners have between two to five people who assist in the } \\
\text { day to day running of the business } \\
\text { The educational level of the respondents was found to not have any impact on the number of people } \\
\text { employed by Micro Enterprises. }\end{array}$ \\
\hline Nature of business & $\begin{array}{l}\text { A large number of the respondents (46\%) were selling groceries } \\
\text { Almost two thirds of respondents (61\%) selling groceries are male. } \\
\text { Different gender has different objectives of starting the business and that the type of business that they } \\
\text { start varies. (Figure 1) }\end{array}$ \\
\hline Start-up capital & $\begin{array}{l}\text { The study showed that most respondents (70\%) used their personal savings to start the business, while } \\
\text { some }(16 \%) \text { used borrowed funds }\end{array}$ \\
\hline $\begin{array}{l}\text { Knowledge of supplier of } \\
\text { goods and services }\end{array}$ & $\begin{array}{l}\text { Almost half of the respondents (44\%) came to know of their supplier of goods and services through } \\
\text { workshops that they attended, while a lesser number (11\%) learnt of them by word of mouth from family } \\
\text { and friends. } \\
\text { More than a half of male respondents are familiar with their suppliers' details, suggesting that they are } \\
\text { more involved with their suppliers' than the female respondents. }\end{array}$ \\
\hline
\end{tabular}

Table 3: Education level by gender

\begin{tabular}{|c|c|c|c|c|c|}
\hline & No formal education & Primary schooling & Junior secondary & Senior secondary & Tertiary education \\
\hline Male & $2 \%$ & $4 \%$ & $22 \%$ & $22 \%$ & $10 \%$ \\
\hline Female & $0 \%$ & $0 \%$ & $8 \%$ & $14 \%$ & $18 \%$ \\
\hline
\end{tabular}




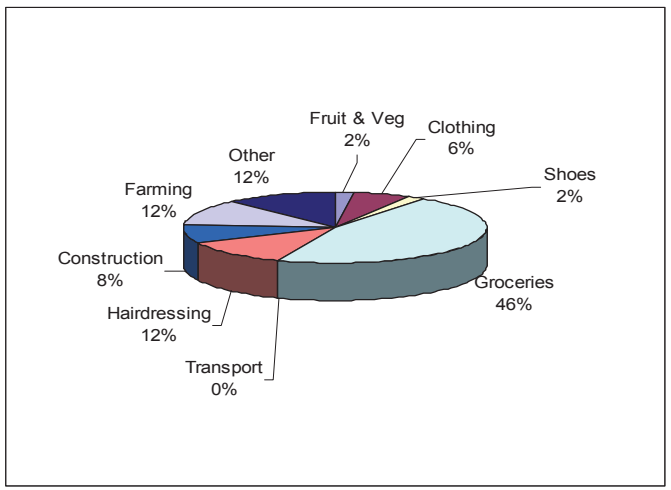

Figure 1: Nature of business

\subsection{Nature of customer-supplier relationships}

The customer-supplier relationships can be gauged by the Micro Enterprise's knowledge of the goods and services, contact details of the supplier, the relationship with specific persons at the suppliers, level of service received, delivery times of goods by suppliers, length of doing business with the current supplier, and special rates offered by the supplier. It was found that the majority of the respondents (70\%) know their supplier's contact details, and most Micro Enterprises that buy on credit from a supplier have the supplier's details.

Many respondents (56\%) indicated that they deal with only a specific contact person at their suppliers. It was further found that almost all respondents, who deal with a specific person at their suppliers, have business training. This could mean that business training modules include information on how to present an application or a business plan when applying for credit from institutions or businesses. It was also found that all those that deal with a specific person at the suppliers receive special rates. It is interesting that most respondents (62\%) that sell groceries deal with a specific person.

The survey showed that almost all the respondents (92\%) received satisfactory service in various degrees from their suppliers (14\% always, $34 \%$ usually, and $44 \%$ sometimes). Receiving satisfactory services from suppliers also assist businesses to strengthen their relationships with suppliers. This is because a satisfied customer is more likely to come back for repetitive purchases, than someone who is not at all satisfied by the services received. Brink \& Berndt (2004: 27) supports this and maintain that interacting with a customer to learn how satisfied the customer is, or whether the customer has an unspoken complaint, is another way of obtaining information about the customers' needs and this enhances relationships.

Over two thirds of the respondents (66\%) that buy goods from suppliers indicated that they receive the goods in time. This is supported by further testing (Chi-square). Punctuality in the delivery of goods and services is indicated as another successful strategy used by suppliers to build a relationship with their customers, in order to ensure repetitive purchases.

It is assumed that the number of years that respondents have been dealing with a supplier indicates their satisfaction with one another. However, the study shows that more than half of the respondents have not been with their current supplier long enough to justify the existence of the relationship. None of them have been dealing with their suppliers for longer than 10 years. This might be an indicator of the absence of a closer relationship and could be one of the reasons why only a few businesses are able to obtain credit.

From the study, it appears that the type of business being operated has an impact on the length of time that suppliers have been dealt with. For instance, all respondents selling groceries have been dealing with their current suppliers for longer than all the other types of businesses. Most of these are male respondents; and again, this may indicate that males are more committed to building and maintaining a close business relationship.

Suppliers of credit often offer special rates, in some cases in the form of discounts, to their customers in an attempt to encourage them to buy more frequently. It was found that more female respondents receive discounts from the suppliers than their male counterparts. This possibly means that the females are good negotiators, or that suppliers prefer them to the male respondents. The research further indicated that respondents who sell groceries have a better chance 
of obtaining special rates because of their frequent contact with the suppliers. Once more, it is found that an increased number of respondents who deal with a specific person receive special rates

\subsection{Nature and accessibility of credit facilities for Micro Enterprises}

All the respondents who indicated that they had access to credit from banks mentioned that it was in the form of loans. None of them obtained bank overdrafts, or factoring. This might be because loan requirements are much easier to meet than that of overdraft or factoring. Migiro (2005:198) suggests that other sources of finance, such as leasing, could be more ideal in meeting Micro Enterprises' financing needs, should they be aware of its existance. He further maintains that this could assist them in the financing of equipment purchases. Leasing accommodates all applicants, whether they have been in business for many years or are in the early stage of developing a business. Leasing only focuses on the borrowers' ability to generate cash flow from business operations to service the lease payment, not on the balance sheet or on past credit history.

The research indicated that most Micro Enterprises did not apply for access to credit. It is assumed that one of the reasons for not applying, is that they were not aware that there are institutions that can assist them with funds. Unfortunately, most of those that applied were rejected. The reasons given for credit rejections were numerous, with the main reason being that the Micro Enterprises did not have collateral to secure the loan.

This supports the findings from previous studies by Migiro (2005:192), concluding that $61.8 \%$ of loan applications by Micro Enterprises in Kenya were rejected. The author further refers to a study in Indonesia by Van Dierman (2000); where it was found that less than 20\% of Micro Enterprises surveyed had never applied for bank loans. Migiro (2005:192) argues that most Micro Enterprises do not apply for credit because they assumed they would not be granted a loan, as they did not have collateral.

\subsection{Reasons for lack of access to credit facilities}

Most respondents' application for credit was rejected by institutions. Among the reasons why Micro Enterprises in this study were rejected access to credit, were insufficient collateral, no business plan, and lack of previous references with credit institutions. Migiro (2005:194) maintains that there are four main reasons why Micro Enterprises in Kenya would not apply for any bank loan; these were high interest rates, collateral, a short repayment period and the lengthy loan screening process.

Applicants are required to offer collateral to secure the loan. This procedure is used by institutions to recover the amount advanced to borrowers when they are not able to repay the loan. Respondents had to offer their movable and immovable assets to secure a loan. The research however, shows that collateral offered by male and female respondents differs, with for instance most female respondents offering furniture to secure a loan. This supposedly makes it easier for the female respondents to obtain credit.

It is held by Kepler \& Shane (2007:9) that women display greater financial risk aversion than men and this carries over to female entrepreneurs. This is supported by the research findings, where it was found that female respondents are usually not offered credit when they do not have collateral, while an exception is sometimes made for males who do not have collateral.

\subsection{Nature of payment terms}

The research showed that the respondents required different credit amounts as they had different reasons in applying for loans. Some businesses were capital intensive and relied on equipment to get the work done, while others, being more labour intensive, relied on employees to get the work done. A capital intensive business tends to require more money to acquire assets required to run the business. For this reason, some respondents needed a loan of between R5 000 and R19 000, while only a few were capital intensive and needed a much larger amount (more than R80 000). The majority of the respondents who required a loan of R5 000 to R19 999, were those selling groceries.

It was found that the amount of credit, the number of years an applicant plans to repay the loan, as well as the collateral provided when applying, sometimes determines the interest rate that has to be paid. The higher the amount required, the higher the interest rate to be paid. Almost half the respondents had to pay 11 to $15 \%$ interest per annum.

Migiro (2005:204-205) agrees with this and maintains that when the applicants do not have a positive track record or collateral, the interest rate would be higher. From this, he concludes that collateral has a close relationship with interest rates. Along this line of reasoning, empirical studies demonstrate that, the larger the collateral a borrower provides, the 
lower the interest rate will tend to be (FAO 1996:5 quoted by Migiro 2005:205).

\subsection{Nature and extend of Micro Enterprises development}

Micro Enterprises' reasons for credit application vary. Some of the reasons mentioned by the respondents were that they wanted to buy equipment, improve their business, buy stock and start the business. Migiro (2005:202) indicates in his study that Micro Enterprises apply for loans for different reasons, such as plant innovation, expansion capacity, replacement and acquisition of machinery and for working capital. This shows that all Micro Enterprises have more or less similar reasons in applying for credit. It was found that most female respondents applied because they wanted to buy stock/goods for their businesses. This is surprising, as the research showed more males selling groceries than females. It is, however, possible that the female respondents wanted to buy stock for their clothing trading, as opposed to groceries.

It was found that most respondents' objectives for credit application were fulfilled after accessing credit. The achievement of their objectives indicates the importance of credit on the development of Micro Enterprises. If they had no business premises before accessing credit, the building or buying of the premises emphasizes that importance. Most respondents bought equipment; some experienced an increase in number of employees, while others had access to telephone lines after accessing credit. Migiro (2005: 184) maintains that the size of the business is measured by the number of employees. Thus, when there is an increase in the number of employees after accessing credit, it can be held that the business is growing.

The research showed that some respondents' turnover increased after accessing credit. This underlines the importance of credit accessibility for a business. The concept is that, when Micro Enterprises have been for instance, generating R5 000 per month before accessing credit, that amount should increase or at least double because of credit obtained. Most respondents' turnover did in fact increase, with only a few that remained the same or did not increase at all.

\section{Conclusions}

\subsection{General}

It is clear from the analysis of the results that male Micro Enterprise owners were dominant in the research area, as is the case in other geographic locations, such as Kenya and the United States. Males are mostly represented in the age categories 20 to 29 years and over 40 years. Added to this, unlike what is generally assumed, many respondents were found to be literate, with at least a secondary education. However, the finance institutions were not found to base their decision to grant credit on the level of education of the applicant. None of the Micro Enterprises' profiles played a role in determining their accessibility to credit facilities. In addition, the nature of the relationship between finance institutions and Micro Enterprises influenced accessibility to credit facilities. In the study, respondents that dealt with a specific person at the supplier/institution were likely to obtain special rates.

It was found that very few respondents had access to credit facilities from banks; all those granted were in the form of bank loans. Most were rejected for credit, while some did not apply, on the assumption that their application would be rejected. Nevertheless, those Micro Enterprises that applied for credit to wholesalers were successful.

The respondents indicated that their applications for credit were rejected for numerous reasons, some of which were insufficient collateral, no business plans and a lack of previous references with credit institutions. Most importantly, those respondents that did obtain credit, experienced positive changes, as a result of the increased facilities.

\subsection{Hypothesis}

The hypotheses formulated reflect that:

H1: A relationship exists between the customer-supplier relationship and credit facilities accessible to Micro Enterprises

This was proven to be true, as a significant number of respondents, who dealt with a specific person at the suppliers/institutions or had the relevant contact details, were able to obtain credit.

$\mathrm{H} 2$ : There is a significant correlation between credit facilities and the nature of Micro Enterprises' development

This was also proven correct as respondents that had access to credit facilities experience positive changes in trading after obtaining credit.

H3: A significant correlation exists between profiles of Micro Enterprises and the accessibility of credit facilities 
This hypothesis was not proven, as there seemed to be no relationship between the profiles of Micro Enterprises and their access to credit

\section{Recommendations that Emerged from the Study}

In order for Micro Enterprises to grow into successful businesses, they need to be trained in entrepreneurship and the operating of a business. This training should include business communication, which could be facilitated by companies and institutions making use of suitable media, such as radio, to inform Micro Enterprises in rural areas about workshops available for their benefit. These could also be used as a platform for institutions and organisations to introduce themselves to business owners.

It is apparent that Micro Enterprises require training in the funding of businesses. For instance, this could be on how to apply for funding and application procedures, because most of the respondents were unaware of such procedures. Micro Enterprises could also be advised of the various forms of funding available, such as leasing and hire purchase contracts. Leasing only focuses on the borrowers' ability to generate a cash flow from business operations to service the lease payment, and not on the balance sheet of the enterprise or past history of trading

\section{References}

Brink, A., \& Berndt, A., (2004). Customer relationship management and customer service. Pretoria: Juta \& Co

Huyghebaert, N., Van de Gucht, L., Van de Hulle, C. (2007). The choice between bank debt and trade credit in business start-ups. Small. Bus. Econ., 2(9): 435-452.

Kepler, E., \& Shane, S. (2007). Are male and female entrepreneurs really different? Small business research summary. United States (Online) Available: http://www.sba.gov /advo/rsearch/rs309tot.pdf. (September 29, 2008)

Kroon, J. (1997). Entrepreneurship: start your own business. Cape Town: Kagiso Publishers

Migiro, S.O. (2005). Small and medium-scale manufacturing enterprises in Kenya: a perspective on alternate sources of financing. Doctorate thesis, University of Zululand, Kwadlangezwa, South Africa

Nieman, G., Hough, J. \& Niewenhuizen, C. (2003). Entrepreneurship: a South African Perspective. (15t Ed.) Pretoria: Van Schaik Publishers

Rogerson, C.M. (2006). Developing SMMEs in peripheral spaces: the experience of Free State Province, South Africa. South African Geographical Journal. 88(1) (Online) Available: http://search.sabinet.co.za/WebZ/images/ejour/sageo/sageo v88 n1 a9.pdf?ses sionid=01-33999-1320937254\&format=F. (May 14, 2008)

Smorfitt, R. (2009). SMEs in South Africa: why is finance difficult to access? (Online). Available: http://innoveur.blogspot.com (January 10, 2010)

South Africa. Department of Trade and Industry. (1998). White paper on national strategy for development of small business in South Africa Cape Town. Parliament of the Republic of South Africa

Van Dierman, P. (2004), The Economic Policy Environment for Small Rural Enterprises in Indonesia, in Thomas Leinbach (ed.), The Indonesian Rural Economy: Mobility, Work and enterprise, Singapore, ISEAS. ISBN 918-230-214-X 